Journal of Contemporary Accounting

\title{
Factors influencing unethical behaviour in banking industry
}

\author{
Analisa \\ Accounting Department, Universitas Sari Mulia, Banjarmasin, Indonesia \\ lisaa1683@gmail.com
}




\title{
Factors influencing unethical behaviour in banking industry
}

\begin{abstract}
Analisa
Accounting Department, Universitas Sari Mulia, Banjarmasin, Indonesia

JEL Classification:

G40, G41

Keywords:

Stress, narcissism, arrogance, work environment, unethical behaviour.

${ }^{*}$ Corresponding Author:

lisaa1683@gmail.com

DOI:

10.20885/jca.vol2.iss2.art4

Copyright @2020

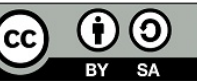

This is an open access under CC-BY-SA LICENSE

Abstract

This study adopts GONE (Greed, Opportunity, Need, Exposure), the Dark Triad and Fraud Pentagon theories to examine the influences of stress, narcissism, arrogance, greed and work environment on unethical behaviour in the banking industry in Special Region of Yogyakarta, Indonesia. The purposive sampling technique is used to recruit 97 respondents. The PLS-SEM (Partial Least Square-Structural Equation Modelling) analysis shows that stress, narcissism, and greed positively and significantly influence unethical behaviour. Arrogance does not influence positively and significantly unethical behaviour. However, there is a positive and significant relation between arrogance and unethical behaviour in the work environment. This study only used unethical behaviour as an indicator. Further research should experiment on other different indicators and also add intention as an intervening variable.
\end{abstract}

\section{Introduction}

A bank is a business unit which collects people fund in the form of saving and distributes it in the form of credit or others to improve the people welfare. The main function of a bank is a place to collect and distribute people's money. About this function, trust becomes a foundation that must exist in banking. Trust in banking is difficult to explain explicitly because every individual has a different problem related to their trust in banking. Therefore, it is necessary for the banking supervisory institution to play the role and at the same time to make a regulation for the implementation of anti-fraud strategies to monitor and regulate the banking activities as well as to prevent, detect, and investigate fraud. Inevitably, the bank can improve its system and gain more trust from the community.

In Indonesia, it is not only government officials of the executive, legislative, and judiciary who can undertake fraud, but private individuals can do so (Hamdani et al., 2017). Fraud committed by management in a company is usually an abuse of authority over financial reporting (Sunaryo et al., 2019). When a bank still employs the same official to carry out various financing activities, it can lead to fraud if its activities lack supervision (Hamdani \& Albar, 2016).

The general modes of fraud or cheating in banking are false recording, transactions without change of ownership, information misrepresentation, abuse of authority, credit card violation and misuse (Haryanti \& Nuryatno, 2018). The misconducts are usually perpetrated by the employees to benefit themselves (Fehr et al., 2019). The fraud eventually impacts the bank and customers, and if the number of frauds increases every year, it will significantly reduce people trust in banking (Kusumaningsih \& Wirajaya, 2017). Therefore, the banks need to be aware of fraud and detect unethical behaviour. Thus, it is necessary to identify the factors causing unethical behaviour in banking. Departing from this reason, researchers are motivated to intensively examine the factors that cause unethical behaviour of employees. Using the theory of GONE (Greed, Opportunity, Need, Exposure), Dark Triad and Fraud Pentagon, researchers will try 
to describe the factors that cause unethical behaviour, especially those committed by banking industry employees in the Special Region of Yogyakarta province.

\section{Literature Review}

\section{Stress}

According to Liu et al. (2018), stress is a condition where a relationship between an individual and his surroundings is perceived as dangerous by the individual. This definition focuses on an individual reaction and refers to stress as a subjective perspective toward unpredictable and insurmountable change. Hong (2019) assumes that work stress is a result of the interaction between an individual and his environment. If in the environment there is an occurrence or contextual factor that causes stress, the individual will feel pressured and anxious. If this condition is not managed properly, there will be an adverse response or consequence.

\section{GONE Theory}

The root causes of one's unethical behaviour (fraud) involve (Bologna, 1992). The first Greed, which comes from an individual potential himself; the second opportunity, which results from a condition in an organization, an institution, or a community that enables an individual to cheat; the third need, which is related to an individual life necessities fulfilment; and fourth exposes, which are related to punishment or consequences faced by the perpetrator when arrested.

This research adopted greed as a variable to investigate unethical behaviour perpetrated by an individual. Greed might be one of the factors driving someone to cheat. Some people commit fraud because naturally humans are greedy and never satisfied with what they have (Sasongko et al., 2019). Seuntjens et al. (2019) state that greed is an unsatisfiable desire over something. A greedy person often fails to control himself and strives to get more, yet he is never satisfied with what he has and his existing condition.

\section{Dark Triad Theory}

The factors of the Dark Triad theory describe all the natures influencing the dominant behaviour in human. One of which is the narcissism which is connected to impulsive attitude and can be developed in a short-term interaction (Lee et al., 2013). According to Jones (2014), an individual who has a high level of any dominant characteristics in Dark Triad factors will tend to be selfish, cold-hearted, and unethical which can lead to cheating. Thus, Dark Triad is often associated with an increase in criminal activities, including fraud and other unethical behaviour Harrison et al. (2018). Lee et al. (2013) argue that the variables of the Dark Triad influence any decision to commit unethical behaviour in any context. This also makes it an individual difficult to develop and maintain a trusted relationship with his co-workers.

Narcissism is used in this study to see its influence on unethical behaviour. Normore (2016) describe narcissism as a distorted self-perspective. Being narcissistic might not be tolerant to criticisms from superiors or stakeholders, cannot compromise with other employees, and surround themselves with the superiors who adore and love them. Narcissism specifically puts oneself ego higher than others' and the individual will tend to prioritise his rights above the others' which might lead to greed (Bailey, 2019). In addition, a narcissistic person tends to be ostentatious about his ability and thinks that he is more important than others. This attitude drives someone to become arrogant and seek attention (Harrison et al., 2018).

\section{Fraud Pentagon Theory}

Fraud Pentagon theory is an expansion of the fraud triangle and fraud diamond. In the fraud triangle, there are three factors that trigger cheating, those are pressure, opportunity, and 
rationalization (Tuanakotta, 2007). Meanwhile, in fraud diamond, one element is added, namely capability (Ristianingsih, 2017). Fraud Pentagon adds two more risk factors, namely competence and arrogance. Competence is one's ability to commit fraud. For example, a high position in a company enables someone to commit unethical behaviour. Arrogance is an attitude that is owned by someone who feels that internal control, policies, and regulations existing in a company do not affect him since he has immunity against them.

This study used arrogance as another variable to examine unethical behaviour. An arrogant person will not feel guilty for what he has done and he will not be remorseful even though he did something unethical.

\section{Work Environment}

The work environment is influenced by many factors including company culture. Sardzoska and Tang (2012) explain that good work will result in work satisfaction and reduce unethical behaviour. Work environment indicates how a situation in the worksite can influence the employee's behaviour. An employee tends to imitate the behaviour existing in the workplace. For example. If an employee sees other employees behave righteously, he tends to imitate the behaviour (Urumsah et al., 2018; Wicaksono \& Urumsah, 2016).

\section{Influence of Stress on Unethical Behaviour}

Logically, stress can influence unethical behaviour since stress is defined as a condition where a relationship between an individual and his surroundings is perceived as dangerous by the individual (Liu et al., 2018). When stress occurs, a person will be pressured and anxious. In this situation, the stressed employee will be more tolerant of unethical activities which benefit the customers from ethically problematic behaviour. A stressed individual tends to interpret low-level activities which can increase the possibility of unethical behaviour. (Hong, 2019) reveals that employees' work stress has a positive and significant influence on their negative behaviour. To be more specific, an employee with a high level of stress has more negative behaviour compared to another employee with a low level of stress. Based on the description, the first hypothesis in this research is:

$\mathbf{H}_{1}$ : Stress positively influences unethical behaviour.

\section{Influence of Greed on Unethical Behaviour}

One of the factors which drives someone to cheat. Some people commit fraud because basically human has greedy nature and is never satisfied with what he has or what he has achieved. Greed is deemed unethical. Being greedy means taking more than needed which can harm others especially during scarcity. The relation between greedy and unethical behaviour might be caused by weak self-control Sasongko et al. (2019). When a person wants to be prosperous but has weak self-control and easily trapped in a lucrative situation, the possibility of the person committing something unethical is getting larger. Based on the description, the second hypothesis in this research is:

$\mathbf{H}_{2}$ : Greed positively influences unethical behaviour.

\section{Influence of Arrogance on Unethical Behaviour}

Logically, arrogance can trigger unethical behaviour because arrogance is an attitude where someone feels proud of himself and looks down on others. A person with arrogance will not feel guilty for his misconduct, so when he commits unethical behaviour, he will not feel remorse. Toscano et al. (2018) state that arrogance will result in lacks of solidity, collaboration, and involvement in a team which might lead to a self-centred attitude that triggers unethical behaviour to take place. However, this is the different result of a study by Sasongko et al. (2019) 
that arrogance has no effect on cheating. Based on the description, the third hypothesis in this research is:

$\mathbf{H}_{3}$ : Arrogance positively influences ethical behaviour.

\section{Influence of Narcissism on Ethical Behaviour}

Narcissism is able to cause ethical behaviour since narcissism is a natural behavioural syndrome involving selfishness, weak self-control, attention-seeking, and interpersonal exploitation. This is supported by the study conducted by Blair et al. (2017) which mentions that narcissism tends to behave unethically since a narcissistic person ignores others' inputs, criticises critical opinions, and imposes his opinion. Besides, Harrison et al. (2018) state that narcissism significantly but not substantively influences unethical behaviour. Based on the description, the fourth hypothesis in this research is:

$\mathbf{H}_{4}$ : Narcissism positively influences unethical behaviour.

\section{Influence of Arrogance on Work Environment}

Arrogance is an attitude that demonstrates superiority and a lack of awareness caused by greed and the idea that company internal control does not apply personally to them. Arrogance always considers himself more important than others, so he tends to be arrogant. Arrogance can adversely affect the work environment, as research conducted by the Committee of Sponsoring Organizations of the Treadway Commission (COSO) found that, $70 \%$ of fraud perpetrators have a profile that is a combination of pressure with arrogance and greed. Toscano et al. (2018) found that arrogance will lead to a situation where there is a lack of cohesiveness, elaboration and team involvement in work so that this will lead to ego attitudes in each individual which can lead to unethical behaviour. Based on the description, the fifth hypothesis in this research is:

$\mathbf{H}_{5}$ : Arrogance positively influences the work environment.

\section{Influence of Work Environment on Unethical Behaviour}

The work environment can logically influence unethical behaviour. This is because the work environment delineates the situation at the workplace which might affect the employees' behaviour. An employee tends to imitate what other employees do in the same work environment because the employee tries to adapt himself to his surroundings. Suryana and Sadeli (2015) argue that the work environment positively influences the tendency to cheat. Agnihotri and Bhattacharya (2019) mention that it is a habit to hide our partner's misconduct and work together to get the benefit, and this act may bring about fraud. Based on the description, the sixth hypothesis in this research is:

$\mathbf{H}_{6}$ : Work environment positively influences intention to commit unethical behaviour.

\section{Influence of Work Environment as Intervening Variable on Unethical Behaviour}

According to Sardzoska and Tang (2012), a good work environment will create work satisfaction and reduce unethical behaviour. Work environment describes the situation of the workplace which can affect employees' behaviour since an employee tends to imitate the habits of other employees in the same work environment. Hence, when one employee does something unethical, (like being arrogant), the other employees might do so Wicaksono and Urumsah (2016). If this condition is cultivated in a work environment, it might trigger unethical behaviour. Based on the description, the seventh hypothesis in this research is:

$\mathbf{H}_{7}$ : Arrogance indirectly influences unethical behaviour with the work environment as an intervening variable. 


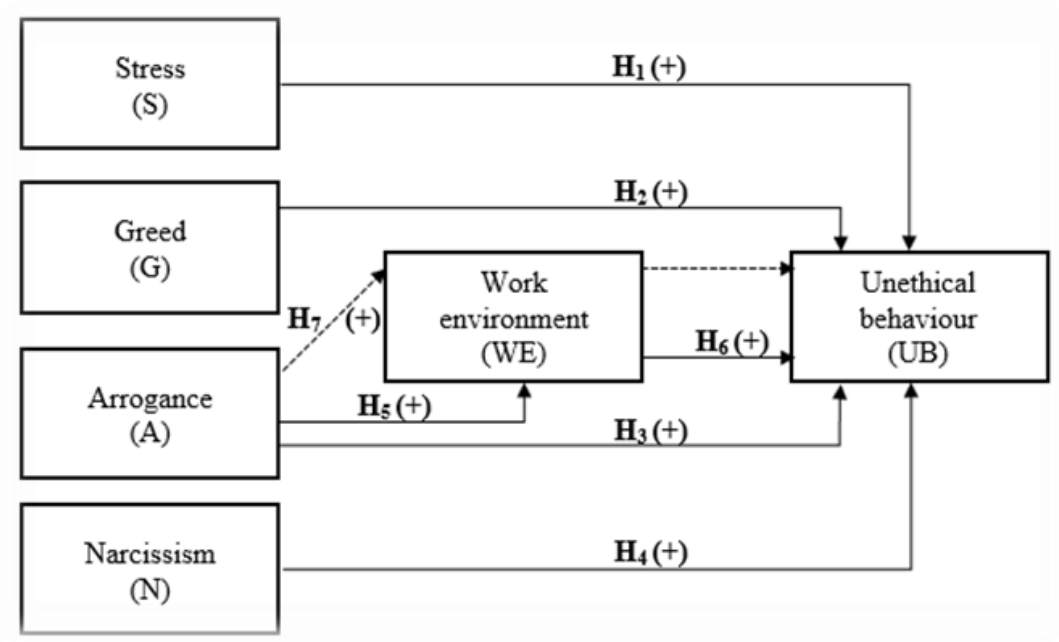

Figure 1. Research model

\section{Research Method}

The data used in this study were primary data that were directly collected from the sources without any intermediaries. The technique of data collection was a questionnaire that was distributed to the employees of the banking industry in Special Region of Yogyakarta as the research sample. The sampling technique employed was purposive sampling with the criteria: 1) permanent or temporary employee in a bank; 2) the employment status is not due to the third party; 3) complete the data of respondent identity as required in the questionnaire including sex, age, latest educational level, employment status, and term of office.

\section{Data Analysis Method}

\section{Outer Model}

A validity test on the items of the questionnaire was conducted to investigate whether or not the items were capable to accurately measure the intended concept of this study. The construct validity test involved the testing on convergent validity and discriminant validity. Using Partial Least Square (PLS) method, the parameters used to measure the convergent validity were loading factor with the rule of thumb $>0.7$, Average Variance Extracted (AVE) with the rule of thumb 0.5 and commonality with the rule of thumb $>0.5$. Additionally, the discriminant validity test used a crossloading parameter with the rule of thumb $>0.7$ in one variable (Sekaran \& Bougie, 2016).

The reliability test is to measure the consistency of the tool in measuring the concept or to measure the consistency of respondents in answering the items of the questionnaire. This study used a composite reliability test to measure the real value of the construct with the rule of thumb $\alpha>0.7$, however, 0.6 was still acceptable.

\section{Structural model (Inner Model)}

PLS model is evaluated using $\mathrm{R}^{2}$ for dependent construct with path coefficient value or $\mathrm{t}$-value for each path to test the significance between the construct and the structural model. If $\mathrm{R}^{2}$ value is close to 1, it means that the influence is getting bigger. In addition to r-squared test, there is tstatistic test to examine the constant significance of each independent variable in one equation to see whether or not the variables individually influence the dependent variable. If t-statistic is larger than t-table, the hypothesis is accepted and proved significant. Hypothesis testing can also be performed using a comparison between path coefficient result and $\mathrm{t}$-table. The hypothesis can be deemed significant if $\mathrm{t}$-statistic $>\mathrm{t}$-table with a significance level $(\alpha) 5 \%$. 


\section{Path analysis}

In this study, the work environment is an intervening variable. The intervening variable is a variable that might be able to influence the relationship between an independent variable and a dependent variable. To test the significance of indirect influence, ab coefficient must be calculated first. The result is t-statistic compared to t-table $\geq 1.96$ with a significance level of $5 \%$. If t-statistic is larger than t-table, it can be concluded that there is a mediating influence (Sekaran \& Bougie, 2016).

\section{Results and Discussion}

\section{Respondent Characteristics}

The number of respondents in this study was 97 . Based on gender, most of the respondents were female as many as 53 people or $54.6 \%$. In terms of age group, most of the respondents were in their 20-30s numbering 69 people $(71,1 \%)$. Most of the respondents were university graduates numbering 74 people $(77 \%)$. In addition, the majority worked as permanent employee in the banking industry.

\section{Outer model Test}

There are three criteria in data analysis technique using Smart-PLS to test the outer model, namely convergent validity, discriminant validity, and composite reliability. The results of the test on those three criteria are presented in Table 1.

Table 1. Results of Measurement Model and Structural Model Tests

\begin{tabular}{|c|c|c|c|c|c|}
\hline Variable & Item & Loading factor & AVE & Composite Reliability & r-squared \\
\hline Stress & S1 & 0.521 & 0.558 & 0.860 & \\
\hline \multirow[t]{4}{*}{ (S) } & S2 & 0.835 & & & \\
\hline & S3 & 0.749 & & & \\
\hline & S4 & 0.728 & & & \\
\hline & S5 & 0.852 & & & \\
\hline \multirow{4}{*}{$\begin{array}{l}\text { Greed } \\
(\mathrm{G})\end{array}$} & G1 & 0.603 & 0.657 & 0.882 & \\
\hline & G2 & 0.903 & & & \\
\hline & G3 & 0.928 & & & \\
\hline & G4 & 0.767 & & & \\
\hline \multirow{4}{*}{$\begin{array}{l}\text { Arrogance } \\
\text { (A) }\end{array}$} & A1 & 0.875 & 0.593 & 0.848 & \\
\hline & A2 & 0.754 & & & \\
\hline & A3 & 0.882 & & & \\
\hline & A4 & 0.507 & & & \\
\hline \multirow{4}{*}{$\begin{array}{l}\text { Narcissism } \\
\quad(\mathrm{N})\end{array}$} & N1 & 0.588 & 0.539 & 0.821 & \\
\hline & N2 & 0.748 & & & \\
\hline & N3 & 0.853 & & & \\
\hline & N4 & 0.724 & & & \\
\hline \multirow{5}{*}{$\begin{array}{l}\text { Work Environment } \\
\text { (WE) }\end{array}$} & WE1 & 0.720 & 0.535 & 0.851 & 0.121 \\
\hline & WE2 & 0.655 & & & \\
\hline & WE3 & 0.740 & & & \\
\hline & WE4 & 0.723 & & & \\
\hline & WE5 & 0.811 & & & \\
\hline \multirow{6}{*}{$\begin{array}{l}\text { Unethical Behaviour } \\
\text { (UB) }\end{array}$} & UB1 & 0.901 & 0.766 & 0.952 & 0.614 \\
\hline & UB2 & 0.924 & & & \\
\hline & UB3 & 0.869 & & & \\
\hline & UB4 & 0.885 & & & \\
\hline & UB5 & 0.836 & & & \\
\hline & UB6 & 0.833 & & & \\
\hline
\end{tabular}


As can be seen in Table 1, the loading factor values are more than 0.5 . The lowest value is 0.507 for indicator A4. This indicates that the indicators used in this study were valid and passed the convergent validity test. Furthermore, the AVE value of each construct in this research is above 0.50 which can be concluded that all constructs in this study also passed the discriminant validity test. The reliability of the construct data can be seen from the result of the composite reliability test. If the result is more than 0.7, the construct is deemed (Sekaran \& Bougie, 2016). This study passed the reliability test with the results as shown in Table 1.

\section{Inner model test}

After passing the outer model test, the inner model test was conducted. The structural model (inner model) test is conducted using R-squared calculation to examine how influential a particular independent variable is on the dependent variable, and path coefficients or $\mathrm{t}$-values of each path are also measured to test the significance among the constructs in the structural model (Hartono \& Abdillah, 2015). R-squared value shows how significant the independent variable can explain the dependent variable. The larger the value of $r$-squared, the more capable the independent variable in explaining the dependent variable, thus a better structural equation can be achieved.

Based on the results presented in Table 1, the values of $r$-squared for the work environment variable is 0.121 and for unethical behaviour is 0.614 . This shows that the arrogance variable can affect the work environment as much as $12.1 \%$, and unethical behaviour is influenced by the variables of stress, narcissism, work environment, and greed as much as $61.4 \%$. The last analysis is hypothesis analysis. The basis used is the output result for inner weight. A relation can be concluded as significant and acceptable if t-statistic value is larger than $\mathrm{t}$-table (with significance level 5\%=1.96).

Table 2. Results of Hypothesis Test

\begin{tabular}{lccc}
\hline \multicolumn{1}{c}{ Variable } & Path Coefficients & t- statistic & Description \\
\hline $\mathrm{S} \rightarrow \mathrm{UB}$ & 0.207 & 2.457 & $\mathrm{H}_{1}$ is supported \\
$\mathrm{G} \rightarrow \mathrm{UB}$ & 0.225 & 2.137 & $\mathrm{H}_{2}$ is supported \\
$\mathrm{A} \rightarrow \mathrm{UB}$ & 0.113 & 1.161 & $\mathrm{H}_{3}$ is not supported \\
$\mathrm{N} \rightarrow \mathrm{UB}$ & 0.290 & 3.576 & $\mathrm{H}_{4}$ is supported \\
$\mathrm{A} \rightarrow \mathrm{WE}$ & 0.348 & 3.872 & $\mathrm{H}_{5}$ is supported \\
$\mathrm{WE} \rightarrow \mathrm{UB}$ & 0.347 & 4.293 & $\mathrm{H}_{6}$ is supported \\
$\mathrm{A} \rightarrow \mathrm{WE} \rightarrow \mathrm{UB}$ & 0.121 & 2.830 & $\mathrm{H}_{7}$ is supported \\
\hline
\end{tabular}

\section{Discussion}

\section{Influence of stress on ethical behaviour}

The result of the hypothesis $\left(\mathrm{H}_{1)}\right.$ analysis indicated that the stress variable positively influenced unethical behaviour. This result is in line with the study of Hong (2019) which states that the work stress of the employees has a positive and significant relationship with their negative behaviour. Specifically, it can be concluded that an employee with a high level of stress tends to have a stronger possibility to commit negative behaviour compared to those with a lower level of stress. Group influence is assumed as one of the sources of stress suffered by an individual. For example, politics in an organization can serve as one of the stress factors in a work environment. Also, social conflicts can cause depression in the employees. This is worsened if the employees lack self-control and psychological endurance.

Therefore, the organization must have a strategy to reduce employee stress, for instance by focusing the policy on the employees, work review and incentive plan outside salary, as well as equal attention. Counselling can be conducted by inviting a psychologist or a religious figure to give spiritual advice. In addition, periodical health and fitness check can be also conducted for the employees in the organization. 


\section{Influence of greed on unethical behaviour}

From the hypothesis $\left(\mathrm{H}_{2}\right)$ testing, it can be concluded that greed positively influences unethical behaviour. This result confirms the study by Seuntjens et al. (2019) which relates greed to unethical behaviour. Naturally, humans have greed and insatiable desires, let alone, weak selfcontrol which will drive a number of people to cheat and behave unethically. In addition, greed in employees is assumed to emerge due to dissatisfaction with their achievements at the workplace either in the form of salary, bonus, or slow promotion process in the organization.

\section{Influence of arrogance on unethical behaviour}

The result of the hypothesis $\left(\mathrm{H}_{3}\right)$ test showed that arrogance did not influence unethical behaviour. Sasongko et al. (2019) mention that arrogance does not influence cheating or unethical behaviour. Arrogance is defined as a desire to show up what an individual owns to others, including showing up his wealth or power, and a tendency to underestimate others. However, this trait cannot directly indicate that the individual has a high probability to behave unethically. If the employees in an organization can control their ego, unethical behaviour can be avoided. An employee who is carefree and ignores any type of intimidation shown by his co-workers will be least likely to commit unethical behaviour.

\section{Influence of narcissism on unethical behaviour}

The hypothesis $\left(\mathrm{H}_{4}\right)$ testing revealed that narcissism influenced unethical behaviour. This result supports the research conducted by Blair et al. (2017) and Harrison et al. (2018) which argue that narcissism influences the tendency to behave unethically. A narcissistic person ignores others' opinion and imposes his perspective. A person with this trait might be intolerant of criticism from his superior or stakeholders and does not compromise those who are against him, so he likes to surround himself with those who support him (Normore, 2016).

A narcissistic employee might feel that he is more superior to others, has delusions of success and power, and craves others' compliments. Generally, a narcissistic person cannot handle criticism and cannot manage insolence well. If that happens to the person, he tends to be upset and underrates others to make him feel better.

\section{Arrogance positively influences unethical behaviour}

The test on the hypothesis $\left(\mathrm{H}_{5}\right)$ resulted in an indication that arrogance positively influenced the work environment. Arrogance is an attitude in which a person neglects internal control, policy, and regulations of an organization; thinks that those rules do not apply to him, and he has immunity against them all (Horwath, 2011). Arrogance can affect the work environment because an arrogant employee tends to boast himself, in terms of fortune, power, or in other forms which might result in underestimating or insulting others. This, of course, will later influence the surrounding people and cause inconvenience at the workplace.

In addition, arrogant behaviour cannot be separated from a person's personality factor. Employees who are arrogant in the work environment will continue to have arrogance in their social environment and the other way. As a result, arrogance creates unethically behaviour which will have a negative impact on the public service process, in this case, the customers in banks at Yogyakarta.

\section{Influence of work environment on unethical behaviour}

From the analysis, it can be concluded that the work environment positively influences unethical behaviour. This finding is similar to the studies conducted by Suryana and Sadeli (2015) and by Agnihotri and Bhattacharya (2019) which reveal that the work environment positively influences 
the tendency to commit unethical behaviour. There are several cases of unethical behaviour at the workplace, however, since the behaviour has been deemed as a habit, it passes unnoticed by the surrounding as long as it does not cause material loss. This phenomenon leads to denial and concealing the fraud or other unethical behaviour perpetrated by their co-workers since it is considered as common.

The work environment delineates the situation at the workplace where an employee tends to imitate the things done by other employees. In this case, Wicaksono and Urumsah (2016) exemplify the fee given by a supplier to an employee so that the supplier's proposal can pass the standard check. Because this action is common at the workplace, this gratification act is deemed normal and even the employee has the justification to accept the gratification. If there is no counteraction to this phenomenon, the employees will tend to hide the unethical behaviour perpetrated by their co-workers.

\section{Influence of work environment as an intervening variable on unethical behaviour}

The hypothesis test result showed that there was an indirect relation between the arrogance variable and unethical behaviour with the work environment as an intervening variable. Arrogant people are identical to people who never feel guilty for their mistakes. They like to boast of what they have to co-works. The presence of an individual or group of arrogant employees will carry out unethical behaviour in the workplace. This is in line with the research of Shintadevi (2015) in her research that shows there are a positive effect and significance between unethical behaviour and the tendency of accounting fraud.

Individual unethical behaviour in the workplace certainly influences the pattern of the working relationship between individual and others. Someone who behaves arrogantly and unethically will be slowly shunned by colleagues. In addition, in a business environment, arrogant and unethical individual behaviour will make it difficult for their self to find new relationships or customers.

\section{Conclusion}

This study is to investigate the contributing factors of unethical behaviour of the employees in banking industries in the Special Region of Yogyakarta Province. Based on the study results, it can be concluded that stress, narcissism, greed, and work environment have positive and significant influences on unethical behaviour. Arrogance positively and significantly influences the working environment. Although arrogance does not significantly influence unethical behaviour, there is an indirect effect positive and significant from arrogance on unethical behaviour with the work environment as an intervening variable.

This study only used unethical behaviour as an indicator. Further research should experiment on other different indicators. Additionally, further researcher can add intention as an intervening variable and interview as another technique to collect data. Also, this study has a limitation in the scope of research since it only examined unethical behaviour of the employees in 11 banking industries in the Special Region of Yogyakarta Province. The questionnaires were also distributed online which made it difficult to detect whether the respondents were indeed the corresponding bank employees or another third party.

\section{References}

Agnihotri, A., \& Bhattacharya, S. (2019). Unethical consumer behavior: the role of institutional and socio-cultural factors. Journal of Consumer Marketing, 36(1), 124-135.

Bailey, C. D. (2019). The joint effects of narcissism and psychopathy on accounting students' attitudes towards unethical professional practices. Journal of Accounting Education, 49, 15-32. 
Blair, C. A., Helland, K., \& Walton, B. (2017). Leaders behaving badly: the relationship between narcissism and unethical leadership. Leadership \& Organization Development Journal, 38(2), 333-346.

Bologna, J. (1992). Handbook on Corporate Fraud: Prevention, Detection, and Investigation. ButterworthHeinemann.

Fehr, R., Welsh, D., Yam, K. C., Baer, M., Wei, W., \& Vaulont, M. (2019). The role of moral decoupling in the causes and consequences of unethical pro-organizational behavior. Organizational Behavior and Human Decision Processes, 153, 27-40.

Hamdani, R., \& Albar, A. R. (2016). Internal controls in fraud prevention effort: a case study. Jurnal Akuntansi \& Auditing Indonesia, 20(2), 127-135. https://doi.org/10.20885/jaai.vol20.iss2.art5

Hamdani, R., Kumalahadi, \& Urumsah, D. (2017). The Classification of Corruption in Indonesia: A Behavioral Perspective. SHS Web of Conferences, 34, 10002. https://doi.org/10.1051/shsconf/20173410002

Harrison, A., Summers, J., \& Mennecke, B. (2018). The effects of the dark triad on unethical behavior. Journal of Business Ethics, 153, 53-77.

Hartono, J., \& Abdillah, W. (2015). Konsep dan Aplikasi PLS (Partial Least Square) untuk Penelitian Empiris. BPFE Yogyakarta.

Haryanti, B. M., \& Nuryatno, M. (2018). The effect of employee compensation and work satisfaction on trends of banking fraud. Jurnal Riset Akuntansi Mercu Buana, 4(2), 106-116.

Hong, N. T. (2019). Unintentional unethical behavior: The mediating and moderating roles of mindfulness. International Journal of Ethics and Systems, 36(1), 98-118.

Jones, D. N. (2014). Risk in the face of retribution: Psychopathic individuals persist in financial misbehavior among the Dark Triad. Personality and Individual Differences, 67, 109-113.

Kusumaningsih, K. U., \& Wirajaya, I. G. A. (2017). Faktor-faktor yang mempengaruhi tindak kecurangan di perusahaan perbankan. E-Jurnal Akuntansi Universitas Udayana, 19(3), 18321860.

Lee, K., Ashton, M. C., Wiltshire, J., Bourdage, J. S., Visser, B. A., \& Gallucci, A. (2013). Kibeom Lee Michael C. Ashton Jocelyn Wiltshire Joshua S. Bourdage Beth A. Visser Alissa Gallucci. European Journal of Personality, 27(2), 169-184.

Liu, Y., Zhao, X., \& Liu, Y. (2018). Stress and unethical consumer attitudes: The mediating role of construal level and materialism. Personality and Individual Differences, 135, 85-91.

Normore, A. H. (2016). The Dark Side of Leadership: Identifying and Overcoming Unethical Practice in Organizations (J. S. Brooks (ed.); Kindle). Emerald Group Publishing Limited.

Ristianingsih, I. (2017). Telaah konsep fraud diamond theory dalam mendeteksi perilaku fraud di perguruan tinggi. Seminar Nasional Ekonomi Dan Bisnis, 128-139.

Sardzoska, E. G., \& Tang, T. L. (2012). Work-related behavioral intentions in Macedonia: coping strategies, work environment, love of money, job satisfaction, and demographic variables. Journal of Business Ethics, 108(3), 373-391.

Sasongko, N., Hasyim, M. N., \& Fernandez, D. (2019). Analysis of behavioral factors that cause student academic fraud. The Journal of Social Sciences Research, 5(3), 830-837.

Sekaran, U., \& Bougie, R. (2016). Research Method for Business Textbook: A Skill Building Approach. Wiley. 
Seuntjens, T. G., Zeelenberg, M., Ven, N. van de, \& Breugelmans, S. M. (2019). Greedy bastards: Testing the relationship between wanting more and unethical behavior. Personality and Individual Differences, 138, 147-156.

Shintadevi, P. F. (2015). Pengaruh keefektifan pengendalian internal, ketaatan aturan akuntansi dan kesesuaian kompensasi terhadap kecenderungan kecurangan akuntansi dengan perilaku tidak etis sebagai variabel intervening. Nominal: Barometer Riset Akuntansi Dan Manajemen, 4(2), 111-126.

Sunaryo, K., Astuti, S., \& Zuhrohtun, Z. (2019). The role of risk management and good governance to detect fraud financial reporting. Journal of Contemporary Accounting, 1(1), 3846. https://doi.org/10.20885/jca.vol1.iss1.art4

Suryana, A., \& Sadeli, D. (2015). Analisis faktor - faktor yang mempengaruhi terjadinya fraud. Jurnal Riset Akuntansi Dan Perpajakan, 2(2), 127-138.

Toscano, R., Price, G., \& Scheepers, C. (2018). The impact of CEO arrogance on top management team attitudes. European Business Review, 30(6), 630-644.

Tuanakotta, T. M. (2007). Akuntansi Forensik \& Audit Investigatif. Lembaga Penerbit Fakultas Ekonomi Universitas Indonesia. https://doi.org/10.1016/j.clay.2015.06.031

Urumsah, D., Wicaksono, A. P., \& Hardinto, W. (2018). Pentingkah nilai religiusitas dan budaya organisasi untuk mengurangi kecurangan? Jurnal Akuntansi Multiparadigma, 9(1), 156-172. https://doi.org/10.18202/jamal.2018.04.9010

Wicaksono, A. P., \& Urumsah, D. (2016). Factors influencing employees to commit fraud in workplace empirical study in Indonesian hospitals. Asia Pacific Frand Journal, 1(1), 1-18. 